\title{
Obligatory N Loss and Utilization of Egg and Rice Mixed Protein in Young Japanese Women
}

\author{
Kayoko KANEKO and Goro KOIKE ${ }^{1}$ \\ Kagawa Nutrition College, 9-21, Chiyoda 3-chome, \\ Sakado-shi, Saitama 350-02, Japan
}

(Received December 24, 1982)

\begin{abstract}
Summary Obligatory urinary and fecal $\mathbf{N}$ losses in young Japanese women were evaluated and the effect of energy intake on the utilization of rice and egg mixed protein was investigated in subjects receiving a low protein diet. Seven female students were given a protein-free diet for ten days. Feces and 24-h urine samples were collected throughout the period and their nitrogen contents were analyzed. Basal metabolism was measured and the lean body mass was calculated from urinary creatinine excretion by the equation of Forbes. The mean weight loss of the 7 subjects during the ten days was $1.5 \mathrm{~kg}$, the mean obligatory urinary $\mathrm{N}$ loss was $32.3 \pm 5.9 \mathrm{mg} / \mathrm{kg}$ body weight, $1.67 \pm 0.45 \mathrm{mg} / \mathrm{kcal}$ basal metabolism, or $1.68 \pm 0.32 \mathrm{~g} / \mathrm{g}$ creatinine, and the mean obligatory fecal $\mathrm{N}$ loss was $10.1 \pm 2.0 \mathrm{mg} / \mathrm{kg}$ body weight, or $0.51 \pm 0.08 \mathrm{mg} / \mathrm{kcal}$ basal metabolism.

In a second experiment, 17 female subjects were divided into three groups with an energy intake of about $35,42,46 \mathrm{kcal} / \mathrm{kg} \mathrm{BW}$, respectively. During the 7-day experimental period, they were given a low protein diet containing $250 \mathrm{~g}$ of rice and $125 \mathrm{~g}$ of whole egg. The nitrogen contents of the 24-h urine samples and feces collected were analyzed and the nitrogen balance was calculated as the difference between $\mathrm{N}$ intake and urinary and fecal $\mathrm{N}$ excretion. Subjects with an energy intake of $35 \mathrm{kcal} / \mathrm{kg} \mathrm{BW}$ had a negative $\mathrm{N}$ balance, while subjects with an intake of $46 \mathrm{kcal} / \mathrm{kg} \mathrm{BW}$ achieved an apparent positive $\mathrm{N}$ balance. The NPU values of rice and egg mixed protein with energy intake of $35,42,46 \mathrm{kcal} / \mathrm{kg}$ BW were calculated from the $\mathrm{N}$ balance data and the values for obligatory urinary and fecal $\mathrm{N}$ losses in the first experiment as 25, 37 and 54, respectively.
\end{abstract}

Key Words obligatory $\mathrm{N}$ loss, protein utilization, women

Protein requirements for Japanese adults (1979)(l) are calculated by the factorial method depending on the estimated obligatory nitrogen loss and the efficiency of utilization of food protein. However, the figures for obligatory $\mathrm{N}$ loss, that is the sum of urinary, fecal and integumental losses, and the data on utilization

\footnotetext{
1 金子佳代子，小池五郎
} 
of food protein have been estimated in Japanese males only, not in females. In this study, these values were evaluated experimentally in Japanese females.

In the 1973 Report (2), the Joint FAO/WHO Ad Hoc Expert Committee on Energy and Protein Requirements stated that although there was a somewhat lower figure (about $25 \mathrm{mg} \mathrm{N} / \mathrm{kg} \mathrm{BW}$ ) for obligatory urinary $\mathrm{N}$ loss in women (3-5), it might not be reliable. The Committee assessed the same figure for women as for men from the data by Murlin et al. (6) who reported that the difference between men and women was not significant. Obligatory fecal $\mathrm{N}$ loss was given as $12 \mathrm{mg} / \mathrm{kg} \mathrm{BW}$ for men and $9 \mathrm{mg} / \mathrm{kg} \mathrm{BW}$ for women in the report of FAO/WHO (1973) (2). For Japanese, however, the same figure $(12 \mathrm{mg} / \mathrm{kg} \mathrm{BW})$ has been applied for both men and women ( 1 .

The effect of the level of energy intake on the efficiency of dietary protein utilization and the $\mathrm{N}$ requirement were examined by Inoue et al. (7) and their results are supported by those of others (8-11). Recently, Nicol and Phillips (12) reported a considerably higher NPU (net protein utilization) of egg protein in Nigerian men than in Japanese or Caucasian men. This fact suggests that the efficiency of protein utilization also depends on environmental and host factors. Most studies on human protein utilization have been made on male subjects, with only a few studies on Caucacian females and none on Japanese female.

The present experiment was planned to evaluate the obligatory urinary and fecal $\mathrm{N}$ losses in young Japanese women. The effect of energy intake on the utilization of rice and egg mixed protein was also investigated in young women receiving a low protein diet. These studies provide fundamental information on the requirement and utilization of protein and energy in women.

\section{EXPERIMENTAL}

Obligatory urinary and fecal $N$ losses. Seven female students of 19 to 23 years old (Table 1A) were given a protein-free diet for 10 days (Table 2). Energy intake in each individual was adjusted to meet the level supplied by an ordinary diet, which was recorded for one or two weeks before the experiment. Then the subjects were given conventional foodstuffs containing the determined energy and about $1.25 \mathrm{~g}$ of protein per $\mathrm{kg}$ body weight for three days. Their body weights did not change significantly during the period on standard diet with an adequate protein intake. So this energy intake was considered as the maintenance level for each person and was maintained throughout the following period on protein-free diet. The mean energy intake of 7 subjects was $33.8 \pm 7.4 \mathrm{kcal} / \mathrm{kg}$ BW, which was 1.7 times the basal metabolic rate. During the experimental period all subjects lived in a metabolic unit and continued their normal daily activities. They were weighed daily before breakfast after voiding urine. Throughout the period 24-h urine samples were collected, and its total nitrogen was measured by the semimicro-Kjeldahl method, and creatinine by Jaffe's reaction(13). Charcoal fecal marker was given before breakfast on the first experimental day and the day after the experimental period. 
Table 1A. Characteristics of young women studied (protein-free diet).

\begin{tabular}{cccccccc}
\hline $\begin{array}{c}\text { Subj. } \\
\text { code }\end{array}$ & $\begin{array}{c}\text { Age } \\
(\mathrm{yr})\end{array}$ & $\begin{array}{c}\text { Height } \\
(\mathrm{cm})\end{array}$ & $\begin{array}{c}\text { Weight }^{\mathrm{a}} \\
(\mathrm{kg})\end{array}$ & $\begin{array}{c}\text { BM }^{\mathrm{b}} \\
(\mathrm{kcal} / \mathrm{kgBW})\end{array}$ & $\begin{array}{c}\text { LBM }^{\mathrm{c}} \\
(\mathrm{kg})\end{array}$ & $\begin{array}{c}\text { LBM/BW } \\
(\%)\end{array}$ & $\begin{array}{c}\text { Energy intake } \\
(\mathrm{kcal} / \mathrm{kgBW})\end{array}$ \\
\hline 101 & 19 & 158 & 55.9 & 18.7 & 38.4 & 68.7 & 28.1 \\
102 & 23 & 162 & 63.2 & 16.4 & 41.3 & 65.3 & 26.8 \\
103 & 20 & 162 & 61.6 & 16.3 & 41.8 & 67.8 & 26.1 \\
104 & 20 & 151 & 40.1 & 20.0 & 28.5 & 71.1 & 37.7 \\
105 & 22 & 168 & 75.2 & 21.0 & 48.6 & 64.6 & 31.9 \\
106 & 21 & 157 & 49.1 & 21.4 & 37.0 & 75.4 & 42.8 \\
107 & 21 & 156 & 46.3 & 26.1 & 27.2 & 58.7 & 43.2 \\
Mean & 20.9 & 159.1 & 55.9 & 20.0 & 37.5 & 67.4 & 33.8 \\
SD & 1.3 & 5.4 & 11.9 & 3.4 & 7.6 & 5.3 & 7.4 \\
\hline
\end{tabular}

${ }^{a}$ Mean weight in the preliminary period. ${ }^{b}$ Measured during the experimental period.

${ }^{c}$ Calculated from the urinary creatinine excretion by the equation of Forbes (1976).

Collected feces were pooled and dried at $100^{\circ} \mathrm{C}$ and their $\mathrm{N}$ contents was determined. Basal metabolism was measured by indirect calorimetry on one day during the experimental period. The lean body mass was calculated from the urinary creatinine excretion by the equation of Forbes and Bruining (14).

Effect of energy intake on the utilization of rice and egg mixed protein. Seventeen female students (Table 1B) were divided into three groups, and given purified, low protein diet with energy intake of about 35,42 and $46 \mathrm{kcal} / \mathrm{kg} \mathrm{BW}$, respectively. Composition of the diet was shown in Table 2. Energy intake was supplied by cornstarch, sugar and shortening. As a protein source, $250 \mathrm{~g}$ of rice and $125 \mathrm{~g}$ of whole egg were given to all subjects without distinction of differences in stature or energy intake. The protein intake was $31.7 \mathrm{~g} /$ day $(5,300 \mathrm{mg} \mathrm{N} /$ day $)$, of which $15.8 \mathrm{~g}$ was supplied from rice and $15.9 \mathrm{~g}$ from egg. Energy from lipid was about $25 \%$ of the total energy intake, which corresponded to that in the habitual Japanese diet. During the study all subjects lived in a metabolic unit. They were weighed daily before breakfast and continued their normal activities. During the 7-day experimental period, feces and 24-h urine samples were collected for analysis and basal metabolism was measured. The nitrogen balance was calculated from the average urinary $\mathrm{N}$ excretion in the last 3 days of the experimental period, the mean fecal $\mathrm{N}$ in the 7-day experimental period and the $\mathrm{N}$ intake. As integumental and miscellaneous $\mathrm{N}$ losses were not taken into account in this study, data are shown as apparent $\mathrm{N}$ balances of $\mathrm{N}$ intake and fecal $\mathrm{N}$ and urinary $\mathrm{N}$ loss.

\section{RESULTS}

Oligatory urinary and fecal $N$ losses

Basal metabolism measured on one day during the experimental period and Vol. 29, No. 4, 1983 
Table 1B. Characteristics of young women studied (rice and egg mixed diet).

\begin{tabular}{|c|c|c|c|c|c|c|c|}
\hline $\begin{array}{c}\text { Energy intake } \\
\text { level } \\
\text { (kcal/kg BW) }\end{array}$ & $\begin{array}{l}\text { Subj. } \\
\text { code }\end{array}$ & $\begin{array}{l}\text { Age } \\
(\mathrm{yr})\end{array}$ & $\begin{array}{l}\text { Height } \\
(\mathrm{cm})\end{array}$ & $\begin{array}{c}\text { Weight }^{\mathrm{a}} \\
(\mathrm{kg})\end{array}$ & $\begin{array}{c}\mathrm{BM}^{\mathrm{b}} \\
(\mathrm{kcal} / \mathrm{kg} \mathrm{BW})\end{array}$ & $\begin{array}{l}\mathrm{LBM}^{\mathrm{c}} \\
(\mathrm{kg})\end{array}$ & $\begin{array}{c}\text { LBM/BW } \\
(\%)\end{array}$ \\
\hline \multirow[t]{5}{*}{46} & 201 & 19 & 158 & 46.0 & 24.9 & 34.1 & 74.1 \\
\hline & 202 & 20 & 151 & 40.8 & 27.1 & 34.3 & 84.1 \\
\hline & 203 & 20 & 148 & 51.0 & 21.3 & 33.6 & 65.9 \\
\hline & Mean & 19.7 & 152.3 & 45.9 & 24.4 & 34.0 & 74.7 \\
\hline & SD & 0.6 & 5.1 & 5.1 & 2.9 & 0.4 & 9.1 \\
\hline \multirow[t]{10}{*}{42} & 204 & 22 & 161 & 49.9 & 25.1 & 34.2 & 68.5 \\
\hline & 205 & 21 & 160 & 45.1 & 23.9 & 37.6 & 83.4 \\
\hline & 206 & 22 & 153 & 46.5 & 19.3 & 34.2 & 73.5 \\
\hline & 207 & 21 & 160 & 56.3 & 19.6 & 42.0 & 74.6 \\
\hline & 208 & 22 & 166 & 52.7 & 22.8 & 37.1 & 70.4 \\
\hline & 209 & 23 & 155 & 58.1 & 21.4 & 38.0 & 65.4 \\
\hline & 210 & 21 & 153 & 49.1 & 20.4 & 29.9 & 60.9 \\
\hline & 211 & 21 & 148 & 41.8 & 22.3 & 30.6 & 73.2 \\
\hline & Mean & 21.6 & 157.0 & 49.9 & 21.9 & 35.5 & 71.2 \\
\hline & SD & 0.7 & 5.8 & 5.6 & 2.1 & 4.0 & 6.7 \\
\hline \multirow[t]{8}{*}{35} & 212 & 20 & 159 & 52.7 & 22.7 & 36.6 & 69.4 \\
\hline & 213 & 22 & 153 & 55.5 & 20.9 & 36.5 & 65.8 \\
\hline & 214 & 23 & 159 & 56.0 & 21.0 & 41.5 & 74.1 \\
\hline & 215 & 21 & 148 & 48.9 & 19.6 & 35.2 & 72.0 \\
\hline & 216 & 19 & 158 & 58.5 & 18.4 & 36.3 & 62.0 \\
\hline & 217 & 23 & 162 & 62.1 & 16.7 & 34.8 & 56.0 \\
\hline & Mean & 21.3 & 155.0 & 55.6 & 19.9 & 36.8 & 66.6 \\
\hline & SD & 1.6 & 5.5 & 4.6 & 2.1 & 2.4 & 6.7 \\
\hline \multirow[t]{2}{*}{ Overall } & Mean & 21.2 & 156.0 & 51.2 & 21.6 & 35.7 & 70.2 \\
\hline & SD & 1.3 & 5.4 & 6.0 & 2.6 & 3.2 & 7.3 \\
\hline
\end{tabular}

${ }^{a}$ Weight on the first day of the experimental period. ${ }^{\mathrm{b}}$ and ${ }^{\mathrm{c}}$ see Table $1 \mathrm{~A}$.

lean body mass, calculated from urinary creatinine, are shown in Table 1A. The mean basal metabolism was $20.0 \pm 3.4 \mathrm{kcal} / \mathrm{kg} \mathrm{BW}$, the mean lean body mass was $37.5 \pm 7.6 \mathrm{~kg}$ and the percentage of lean body mass to body weight was $67.4 \pm 5.3 \%$. Table 3 shows the change in body weight and the obligatory urinary and fecal $\mathbf{N}$ losses. In all subjects, body weight decreased significantly during the period on protein-free diet: the mean weight loss of the 7 subjects during 10 days was $1.5 \pm 0.8 \mathrm{~kg}$. Urinary total $\mathrm{N}$ excretion decreased gradually, reaching a steady state on days $7-10$ (Fig. 1). The average values in the last 4 days, from days $7-10$ of the experimental period, was regarded as the obligatory urinary $\mathrm{N}$ loss for each 
Table 2. Composition of experimental diet. ${ }^{\mathrm{a}}$

\begin{tabular}{lcc}
\hline \multirow{2}{*}{ Ingredient } & \multicolumn{2}{c}{ Intake $(\mathrm{g} /$ day $)$} \\
\cline { 2 - 3 } & Protein free diet & Rice and egg mixed diet \\
\hline Rice & - & 250 \\
Whole egg & - & 125 \\
Cornstarch & 207 & 30 \\
Sugar & 123 & 65 \\
Shortening & 48 & 21 \\
Agar & 5 & 5 \\
Sodium chloride & 3 & 3 \\
Vitamin mixture $^{\mathrm{b}}$ & 2 tablets & 2 tablets \\
Mineral mixture $^{\mathrm{c}}$ & 4 & 4 \\
\hline
\end{tabular}

${ }^{a}$ Intake is given for a subject receiving, $1,600 \mathrm{kcal} / \mathrm{day}$. Besides this diet, the subjects consumed black tea, green tea and lemon juice. ${ }^{\mathrm{b}}$ Two tablets of vitamin mixture contained: retinyl palmitate, $2,000 \mathrm{IU}$; vitamin $\mathrm{D}_{2}, 200 \mathrm{IU}$; vitamin $\mathrm{B}_{1}$ hydrochloride, $10 \mathrm{mg}$; riboflavin, $4 \mathrm{mg}$; pyridoxine hydrochloride, $6 \mathrm{mg}$; nicotinamide, $50 \mathrm{mg}$; cyanocobalamine, $10 \mu \mathrm{g}$; ascorbic acid, $150 \mathrm{mg} ; \alpha$-tocopherol acetate, $10 \mathrm{mg}$; and Ca pantothenate, $30 \mathrm{mg}$. ${ }^{\mathrm{c}} 100 \mathrm{~g}$ of mineral mixture contained (in g): $\mathrm{CaCO}_{3}, 25.12 ; \mathrm{KHCO}_{3}$, $39.25 ; \mathrm{MgSO}_{4} \cdot 7 \mathrm{H}_{2} \mathrm{O}, 10.78 ; \mathrm{FeC}_{6} \mathrm{H}_{5} \mathrm{O}_{7} \cdot 6 \mathrm{H}_{2} \mathrm{O}, 2.91 ; \mathrm{KH}_{2} \mathrm{PO}_{4}, 21.74 ; \mathrm{MnSO}_{4} \cdot 4 \mathrm{H}_{2} \mathrm{O}$, $0.0369 ; \mathrm{CuSO}_{4} \cdot 5 \mathrm{H}_{2} \mathrm{O}, 0.1306 ; \mathrm{KI}, 0.0073$; and $\mathrm{ZnCl}_{2}, 0.0316$. This mixture was mainly based upon that of Rose et al. (J. Biol. Chem., 182, 541 (1950)).

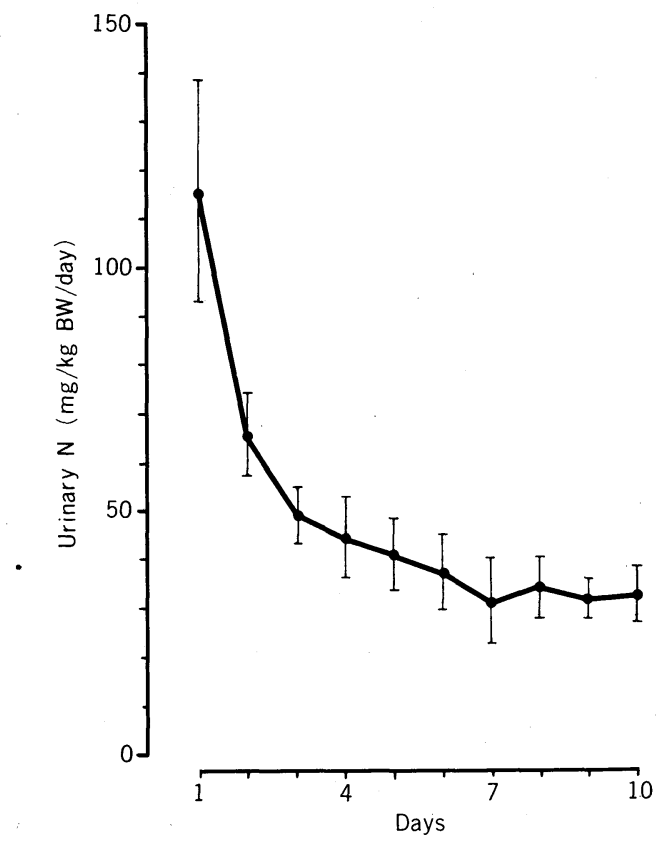

Fig. 1. Urinary $\mathbf{N}$ loss in 7 young women who consumed protein-free diet.

Vol. 29, No. 4, 1983 


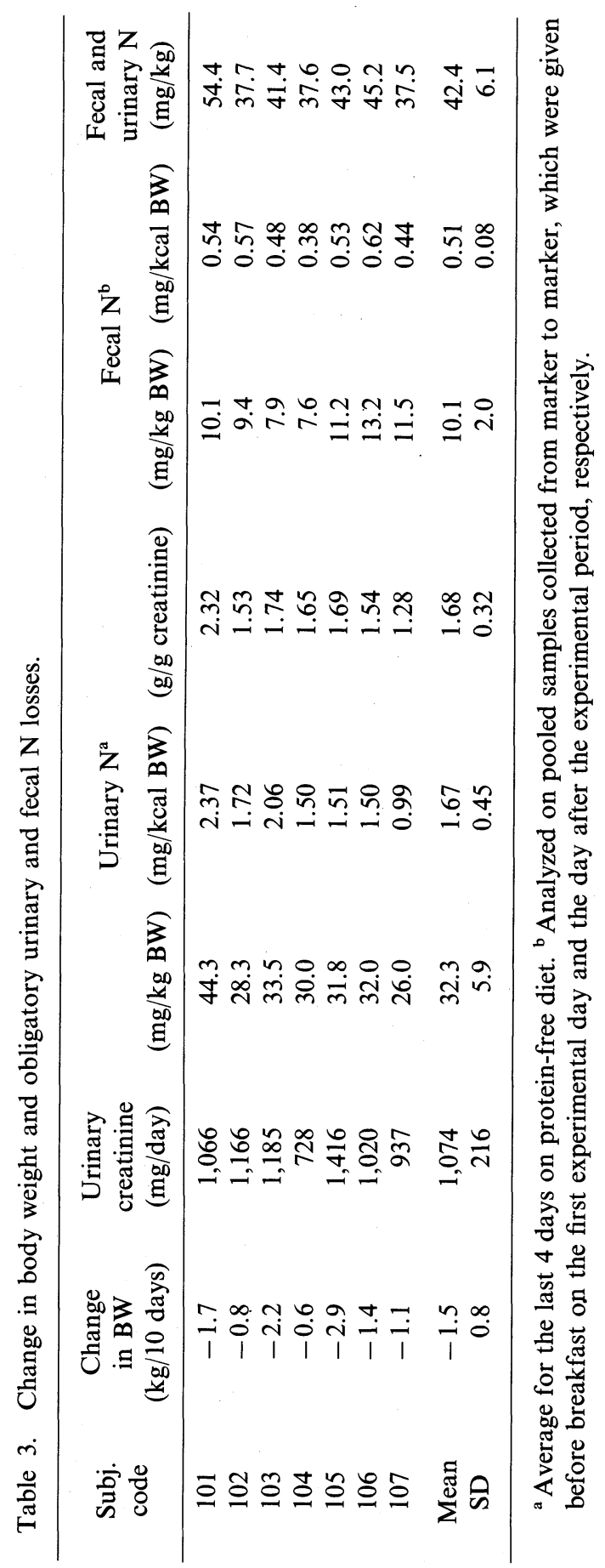


Table 4. Nitrogen balance and body weight of individual subjects given rice and egg mixed diets with various energy levels.

\begin{tabular}{ccccccc}
\hline $\begin{array}{c}\text { Subj. } \\
\text { code }\end{array}$ & $\begin{array}{c}\text { Energy } \\
\text { intake } \\
(\mathrm{kcal} / \mathrm{kg})\end{array}$ & $\begin{array}{c}\mathrm{N} \\
\text { intake } \\
(\mathrm{mg} / \mathrm{kg})\end{array}$ & $\begin{array}{c}\text { Change } \\
\text { in BW } \\
(\mathrm{kg} / 7 \text { days })\end{array}$ & $\begin{array}{c}\text { Fecal }^{\mathrm{a}} \\
(\mathrm{mg} / \mathrm{kg})\end{array}$ & $\begin{array}{c}\text { Urinary } \\
\mathbf{N} \\
(\mathrm{mg} / \mathrm{kg})\end{array}$ & $\begin{array}{c}\text { Nitrogen } \\
\text { balance } \\
(\mathrm{mg} / \mathrm{kg})\end{array}$ \\
\hline 201 & 46.7 & 114.5 & +0.3 & 82.9 & 17.3 & +14.3 \\
202 & 46.2 & 130.8 & -0.3 & 102.9 & 27.5 & +0.4 \\
203 & 44.9 & 103.6 & +0.2 & 59.8 & 18.9 & +24.9 \\
Mean & 45.9 & 116.3 & +0.1 & 81.9 & 21.2 & +13.2 \\
SD & 0.9 & 13.7 & 0.3 & 21.6 & 5.5 & 12.3 \\
\hline 204 & 43.5 & 107.2 & -0.9 & 93.2 & 21.9 & -8.1 \\
205 & 43.3 & 118.4 & -1.4 & 124.4 & 24.8 & -30.8 \\
206 & 43.2 & 114.5 & -1.7 & 111.7 & 15.1 & -12.3 \\
207 & 42.9 & 95.0 & -1.0 & 81.4 & 16.1 & -2.5 \\
208 & 42.5 & 101.3 & -0.8 & 85.1 & 17.5 & -1.1 \\
209 & 41.4 & 92.0 & -0.5 & 70.4 & 15.0 & +6.6 \\
210 & 40.3 & 106.0 & -0.7 & 92.8 & 16.6 & -3.4 \\
211 & 40.2 & 124.4 & -0.3 & 108.9 & 20.6 & -5.1 \\
Mean & 42.2 & 107.3 & -0.9 & 96.0 & 18.4 & -7.1 \\
SD & 1.3 & 11.3 & 0.5 & 17.8 & 3.6 & 11.0 \\
\hline 212 & 37.8 & 98.9 & -1.0 & 107.4 & 16.3 & -24.8 \\
213 & 36.9 & 93.6 & -1.0 & 91.0 & 19.4 & -16.8 \\
214 & 35.7 & 93.0 & -0.6 & 104.1 & 17.6 & -28.7 \\
215 & 34.5 & 106.0 & -0.6 & 103.4 & 16.4 & -13.8 \\
216 & 33.6 & 89.2 & -0.4 & 67.7 & 14.5 & +7.0 \\
217 & 31.8 & 83.9 & -0.6 & 74.9 & 14.6 & -5.6 \\
Mean & 35.0 & 94.1 & -0.7 & 91.4 & 16.5 & -13.8 \\
SD & 2.2 & 7.7 & 0.2 & 16.7 & 1.8 & 13.0 \\
\hline
\end{tabular}

${ }^{a}$ As for Table 3. ${ }^{\mathrm{b}}$ Average for the last 3 days of the experimental period.

individual: the mean obligatory urinary $\mathrm{N}$ loss of the 7 subjects was $32.3 \pm 5.9 \mathrm{mg} / \mathrm{kg}$ $\mathrm{BW}, 1.67 \pm 0.45 \mathrm{mg} / \mathrm{kcal}$ basal metabolism or $1.68 \pm 0.32 \mathrm{~g} / \mathrm{g}$ creatinine. The mean obligatory fecal $\mathrm{N}$ loss of the 7 subjects was $10.1 \pm 2.0 \mathrm{mg} / \mathrm{kg}$ BW or $0.51 \pm 0.08 \mathrm{mg} / \mathrm{kcal}$ basal metabolism.

Effect of energy intake on the utilization of rice and egg mixed protein

The basal metabolism and lean body mass of each subject are shown in Table 1B. Table 4 shows the energy and nitrogen intakes, the change in body weight, the urinary and fecal $\mathrm{N}$ excretions and the apparent $\mathrm{N}$ balance in each subject. The body weights of subjects receiving $46 \mathrm{kcal} / \mathrm{kg} \mathrm{BW}$ tended to increase slightly unlike 


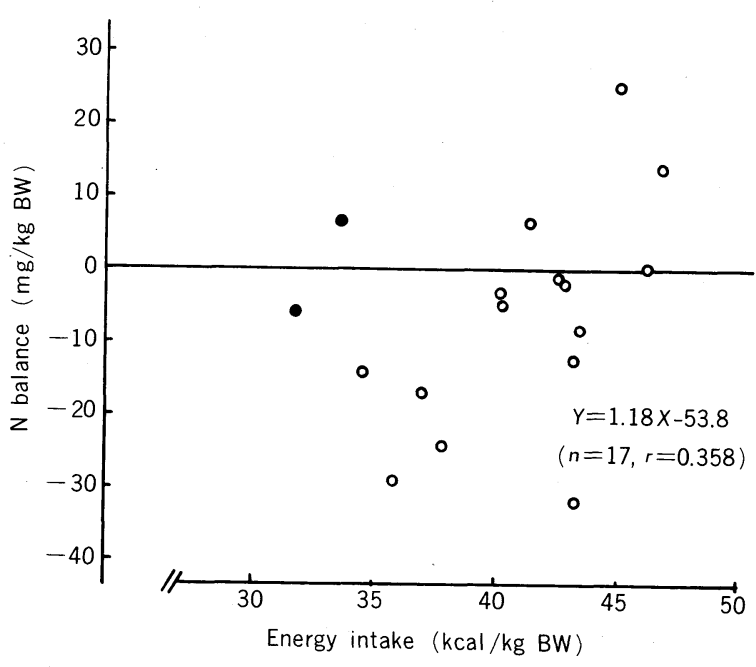

Fig. 2. Correlation between $\mathrm{N}$ balance and energy intake per $\mathrm{kg}$ body weight.

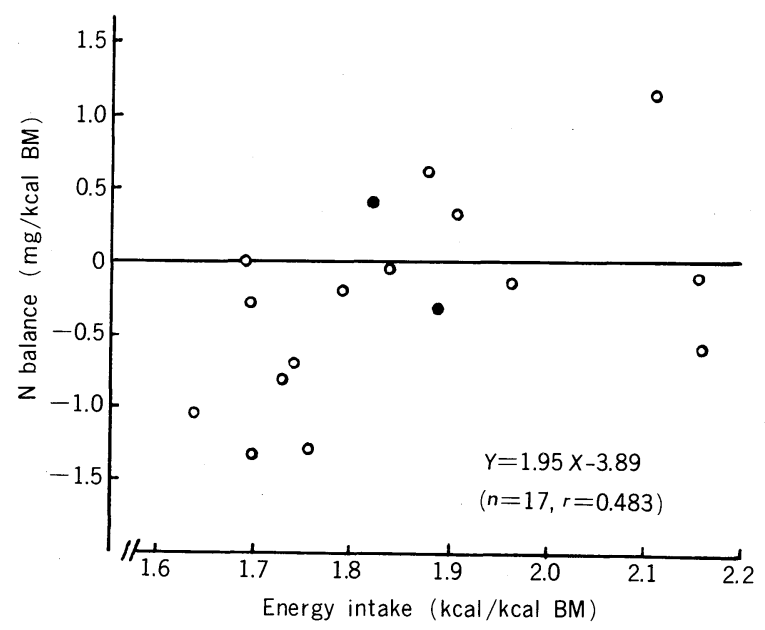

Fig. 3. Correlation between $\mathrm{N}$ balance and energy intake per basal metabolism.

those of subjects receiving 42 or $35 \mathrm{kcal} / \mathrm{kg}$ BW. No significant correlation $(r=0.064)$ was found between $\mathrm{N}$ balance and $\mathrm{N}$ intake, but a significant correlation $(r=0.358)$ was found between $\mathrm{N}$ balance and energy intake calculated per kg body weight (Fig. 2). Subjects with an energy intake of $35 \mathrm{kcal} / \mathrm{kg} \mathrm{BW}$ were in negative $\mathrm{N}$ balance and subjects with an intake of $46 \mathrm{kcal} / \mathrm{kg}$ BW were in apparent positive $\mathrm{N}$ balance. The closed circles in Fig. 2 are for two subjects with low energy intake (less than $35 \mathrm{kcal} / \mathrm{kg} \mathrm{BW}$ ) who maintained an $\mathrm{N}$ balance of approximately zero. These two subjects scarcely lost any body weight. Figure 3 shows the correlation between 
Table 5. Summary of NPU and digestibility of rice and egg mixed diet.

\begin{tabular}{cccccc}
\hline & $\begin{array}{c}\text { Energy } \\
\text { intake } \\
(\mathrm{kcal})\end{array}$ & $\begin{array}{c}\text { No. of } \\
\text { subj. }\end{array}$ & $\begin{array}{c}\mathrm{N} \\
\text { intake } \\
(\mathrm{mg})\end{array}$ & NPU $^{\mathrm{a}}$ & Digestibility $^{\mathrm{b}}$ \\
\hline \multirow{3}{*}{ per kg BW } & $47-45$ & 3 & 117 & 54 & 91 \\
& $44-40$ & 8 & 109 & 37 & 92 \\
& $39-35$ & 4 & 100 & 25 & 93 \\
& $34-30$ & 2 & 88 & 53 & 95 \\
\hline \multirow{3}{*}{ per kcal BM } & $>1.8$ & 9 & 4.89 & 50 & 94 \\
& $<1.8$ & 8 & 4.78 & 33 & 92 \\
\hline \multirow{2}{*}{ per kg LBM } & $70-60$ & 5 & 157 & 51 & 93 \\
& $59-50$ & 9 & 148 & 39 & 93 \\
& $49-40$ & 3 & 138 & 24 & 92 \\
\hline
\end{tabular}

${ }^{\text {a }}$ Calculated using values of $42.4 \mathrm{mg} / \mathrm{kg} \mathrm{BW}, 2.18 \mathrm{mg} / \mathrm{kcal} \mathrm{BM}$ and $63.0 \mathrm{mg} / \mathrm{kg} \mathrm{LBM}$, respectively, for endogenous $\mathrm{N}$ loss. ${ }^{\mathrm{b}}$ Calculated using the values of $10.1 \mathrm{mg} / \mathrm{kg} \mathrm{BW}$, $0.51 \mathrm{mg} / \mathrm{kcal} \mathrm{BM}$ and $15.1 \mathrm{mg} / \mathrm{kg} \mathrm{LBM}$, respectively, for obligatory fecal $\mathrm{N}$ loss determined in the experiment on protein-free diet.

energy intake and $\mathrm{N}$ balance expressed per kcal basal metabolism. These values, including those two subjects shown by closed circles, showed that the apparent $\mathrm{N}$ balance improved with increase in energy intake. When $\mathrm{N}$ balance was expressed per $\mathrm{kg}$ lean body mass, the same tendency and a higher correlation coefficient $(r=0.705)$ was observed. The NPU of rice and egg mixed protein at each level of energy intake was calculated from the $\mathrm{N}$ balance data and figures for obligatory urinary and fecal $\mathrm{N}$ losses (Table 5). The NPUs obtained at energy intake of 45-47, 40-44 and 35-39 kcal/kg BW were 54, 37 and 25, respectively. However, at a low energy intake of $30-35 \mathrm{kcal} / \mathrm{kg} \mathrm{BW}$, a higher NPU value of 53 was observed in two subjects. The average true digestibility of rice and egg mixed protein was calculated as $93 \%$.

\section{DISCUSSION}

The obligatory urinary $\mathrm{N}$ loss of our 7 subjects, $32.3 \pm 5.9 \mathrm{mg} / \mathrm{kg} \mathrm{BW}$, agrees well with the figure of $33.3 \pm 3.1 \mathrm{mg} / \mathrm{kg}$ BW for Japanese men (15). The value for obligatory fecal $\mathrm{N}$ loss for Japanese women obtained in this study, $10.1 \pm 2.0 \mathrm{mg} / \mathrm{kg}$ $\mathrm{BW}$, was a little less than that for men $(12.7 \mathrm{mg} / \mathrm{kg} \mathrm{BW})(15)$.

Is there any racial difference in obligatory urinary $\mathrm{N}$ excretion? $\mathrm{Nicol}$ and Phillips (12) summarized the figures determined in male Caucasian, Chinese, Indian and Nigerian subjects and concluded that there was no essential difference in obligatory urinary $\mathrm{N}$ loss in different races. However, few studies have been made 
on females of different races. Bricker and Smith (4) reported that the obligatory urinary $\mathrm{N}$ excretion of 25 young Caucasian women given protein-free diet for 14 days was $25.2 \pm 3.3 \mathrm{mg} / \mathrm{kg} \mathrm{BW}$. They measured the urinary $\mathrm{N}$ excretion in the last 5 days of the period and reported the mean energy intake of their subjects as $45 \mathrm{kcal} / \mathrm{kg} \mathrm{BW}$. In the report of FAO/WHO (1973)(2), the committee considered that the Bricker and Smith figure was somewhat low and might not be reliable. Recently, Bodwell et al. (16) reported a figure of $30.7 \pm 5.8 \mathrm{mg} / \mathrm{kg} \mathrm{BW}$ for 11 young Caucasian females given a protein-free diet with an energy intake of $41 \pm 2.8 \mathrm{kcal} / \mathrm{kg}$ BW for 15 days and determined the urinary $\mathrm{N}$ excretion in the last 5 days. Jourdan $e t$ al. (17) reported results on obese Caucasian women with a mean body weight of $116.6 \mathrm{~kg}$ when given protein-free diet for 12 days. The obligatory urinary $\mathrm{N}$ excretion of these subjects in the last 5 days was $2.36 \pm 0.09 \mathrm{~g} /$ day. This value per $\mathrm{kg}$ body weight $(20.6 \mathrm{mg} / \mathrm{kg} \mathrm{BW})$ is considerably lower than ours or Bodwell et al., but per $\mathrm{g}$ creatinine $(1.77 \mathrm{~g} / \mathrm{g}$ creatinine) it coincided fairly well with the value of Bodwell et al. $(1.78 \mathrm{~g})$ and with ours $(1.68 \mathrm{~g})$. Since urinary creatinine excretion is closely correlated with lean body mass (14), this agreement suggests that obligatory urinary $\mathrm{N}$ loss is related to the lean body mass. Thus there is no considerable difference between Japanese and Caucasian females in obligatory urinary $\mathrm{N}$ loss per $\mathrm{kg}$ lean body mass or per $\mathrm{g}$ of urinary creatinine. However, expressing obligatory urinary $\mathrm{N}$ loss per basal metabolism, the value for Japanese women $(1.67 \mathrm{mg} / \mathrm{kcal})$ was higher than for Caucasian women $(1.1-1.3 \mathrm{mg} / \mathrm{kcal})(4-6)$. This could be explained, as one factor, by the lower basal metabolism in our subjects. Somewhat low basal metabolism in Japanese young women is also reported by Kikuchi et al. (18). And recently Solomon et al. (19) have reported in Caucasian women a low basal metabolism, $20.7 \mathrm{kcal} / \mathrm{kg}$, which was as much as that in our Japanese subjects. So this problem requires further study. On the other hand, obligatory fecal $\mathrm{N}$ loss of Japanese women $(10.1 \pm 2.0 \mathrm{mg} / \mathrm{kg} \mathrm{BW})$ was slightly higher than that of Caucasian women $(7.7 \mathrm{mg} / \mathrm{kg} \mathrm{BW})(16)$.

Inoue et al. (7) reported that in their male subjects the NPU of egg protein was dependent on energy intake as well as $\mathrm{N}$ intake, and it was suppressed by the deleterious effect of energy restriction and improved by addition of extra energy to diet with an already adequate energy content. The present data on the NPU of rice and egg mixed protein estimated in female subjects with different energy intakes support their results. According to Inoue et al., in men with a maintenance energy intake of $45 \mathrm{kcal} / \mathrm{kg} \mathrm{BW}$, the NPU of egg protein was 55 at the $\mathrm{N}$ intake level for maintenance of apparent $\mathrm{N}$ equilibrium. The present data showed that the NPU of rice and egg mixed protein with energy intake of $40-44 \mathrm{kcal} / \mathrm{kg}$ BW was 37 . We also observed that two female subjects showed high utilization of absorbed protein (NPU 53) with low energy intake per kg BW. When energy intake was expressed per basal metabolism or per lean body mass, these particular subjects could be included in the group with somewhat excess energy intake. In these two subjects, the estimated basal metabolism was $20-30 \%$ lower than the figure calculated from the basal metabolic rate for Japanese women (20) and a percentage of lean body mass 
to body weight was lower, that is a larger content of body fat, than average for Japanese young women. Recently, we observed that several young women had a lower basal metabolism, or larger percentage of body fat, like the subjects described above (21). So we conclude that in calculation of the optimum energy intake for women it is not adequate to calculate the value per body weight or per basal metabolism from the basal metabolic rate for Japanese and that the value should be calculated per estimated basal metabolism or per lean body mass. This problem should be studied further to determine the energy and protein requirements of Japanese women more adequately.

We are grateful to Prof. G. Inoue, The University of Tokushima, for valuable suggestions.

\section{REFERENCES}

1) Committee on Nutrition (Japan) (1979): Dietary protein allowances, In Recommended Dietary Allowances for Japanese, Ministry of Health and Welfare, Tokyo.

2) Report of a Joint FAO/WHO Ad Hoc Expert Committee (1973): Energy and Protein Requirements, World Health/Org. Techn. Rep. Ser. No. 522.

3) Bricker, M. L., Shively, R. F., Mitchell, H. H., and Hamilton, T. S. (1949): The protein requirements of college women on high cereal diets with observations on the adequacy of short balance period. J. Nutr., 37, 163-183.

4) Bricker, M. L., and Smith, J. M. (1951): A study of the endogenous nitrogen output of college women, with particular reference to use of the creatinine output in the calculation of the biological value of the protein of egg and sunflower seed flour. $J$. Nutr., 44, 553-573.

5) Hawley, E. E., Murlin, J. R., Nassett, E. S., and Szymanski, T. A. (1948): Biological values of six partially-purified proteins. J. Nutr., 36, 153-169.

6) Murlin, J. R., Edwards, L. E., Hawley, E. E., and Clark, L. C. (1946): Biological value of proteins in relation to the essential amino acids which they contain. J. Nutr., 31, 533554.

7) Kishi, K., Miyatani, S., and Inoue, G. (1978): Requirement and utilization of egg protein by Japanese young men with marginal intakes of energy. J. Nutr., 108, 658-669.

8) Garza, C., Scrimshaw, N. S., and Young, V. R. (1976): Human protein requirements; the effect of variations in energy intake within the maintenance range. Am. J. Clin. Nutr., 29, 280-287.

9) Garza, C., Scrimshaw, N. S., and Young, V. R. (1977): Human protein requirements; evaluation of the $1973 \mathrm{FAO} / \mathrm{WHO}$ safe level of protein intake for young men at high energy intakes. Br. J. Nutr., 37, 403-420.

10) Garza, C., Scrimshaw, N. S., and Young, V. R. (1977): Human protein requirements; A long-term metabolic nitrogen balance study in young men to evaluate the 1973 FAO/WHO safe level of egg protein intake. J. Nutr., 107, 335-352.

11) Garza, C., Scrimshaw, N. S., and Young, V. R. (1978): Human protein requirements; Interrelationships between energy intake and nitrogen balance in young men consuming the $1973 \mathrm{FAO} /$ WHO safe level of egg protein, with added nonessential amino acids. J. Nutr., 108, 90-96.

12) Nicol, B. M., and Phillips, P. G. (1976): Endogenous nitrogen excretion and utilization

Vol. 29, No. 4, 1983 
of dietary protein. Br. J. Nutr., 35, 181-193.

13) Koishi, H. (1962): A critical examination on the Folin's method for determination of creatinine concentration in the urine. Osaka City Med. J., 8, 1-15.

14) Forbes, G. B., and Bruining, G. J. (1976): Urinary creatinine excretion and lean body mass. Am. J. Clin. Nutr., 29, 1359-1366.

15) Inoue, G., Fujita, Y., Kishi, K., Yamamoto, S., and Niiyama, Y. (1974): Nutritive values of egg protein and wheat gluten in young men. Nutr. Rep. Int., 10, 201-207.

16) Bodwell, C. E., Schuster, E. M., Kyle, E., Brooks, B., Womak, M., Steele, P., and Ahrens, R. (1979): Obligatory urinary and fecal nitrogen losses in young women, older men, and young men and the factorial estimation of adult human protein requirements. Am. J. Clin. Nutr., 32, 2450-2459.

17) Jourdan, M., Margen, S., and Bradfield, R. B. (1974): Protein-sparing effect in obese women fed low calorie diets. Am. J. Clin. Nutr., 27, 3-12.

18) Kikuchi, F., Shimamura, N., and Juen, U. (1979): Body composition and basal metabolism in female students. Proceedings of the 31th annual meeting of Japanese Society of Nutrition and Food Science, p. 44.

19) Solomon, S. J. Kurzer, M. S., and Calloway, D. H. (1982): Menstrual cycle and basal metabolic rate in women. Am. J. Clin. Nutr., 36, 611-616.

20) Committee on Nutrition (Japan) (1969): Recommended Dietary Allowances for Japanese, Ministry of Health and Welfare, Tokyo.

21) Kaneko, K., Amagai, S., and Koike, G. (1981): Basal metabolism and body composition in young women, Proceedings of the 35th annual meeting of Japanese Society of Nutrition and Food Science, p. 133. 